\title{
PERCEPTIONS AND LIPID PROFILES OF MIXED HERBAL DRINK (GARLIC, GINGER, LEMON, HONEY, AND APPLE VINEGAR) CONSUMERS WITH HYPERCHOLESTEROLEMIA
}

\author{
Ahmad Muthi Abdillah ${ }^{1 *}$, Ahmad Sulaeman ${ }^{1}$, Tiurma Sinaga ${ }^{2}$ \\ ${ }^{1-2}$ Community Nutrition Department, Human Ecology Faculty, IPB University, Indonesia \\ E-mail: ahmad.muthi@live.com
}

\begin{abstract}
Cholesterol-lowering herbal treatment made from natural ingredients are believed to be able to replace modern medicine even though it has not been scientifically proven. Purpose of this study was to test perceptions of customers and effects of mixed herbal drink on lipid profile of consumers with hypercholesterolemia. Study was conducted using cross sectional study design consisted of three stages, that is survey, questionnaire data collection, and medical record data collection. The research subjects were selected by stratified random sampling, which subjects were consumers of mixed herbal drink in total of 55 people, both men and women. Data was collected through interviews of questionnaires covering subject characteristics, subject perceptions of mixed herbal drink, and their medical record data before and after consumption of mixed herbal drinks. Paired T-test were used to observe the differences in subject lipid profile before and after consumption of mixed herbal drink. Consumer perceptions toward health aspects showed that $83.7 \%$ of subjects experienced a decrease in cholesterol after consuming mixed herbal drink. Consumer emotional perception showed that $90.9 \%$ of subjects feel healthier and filter after consuming mixed herbal drink. Results of subject medical records on lipid profile showed a decrease in total cholesterol, LDL, and triglycerides $(p<0.05)$. Based on perceptions and medical records, it is known that mixed herbal drink can be used as an alternative to traditional cholesterol-lowering medicines.
\end{abstract}

Keywords: hypercholesterolemia, mixed herbal drinks, consumer perceptions, lipid profiles

\section{BACKGROUND}

Heart disease is one of major causes of death in Indonesia. The 2013 Basic Health Research Report (RISKESDAS) reported that prevalence of coronary heart disease in Indonesia was 1.5\%. One of the main factors of coronary heart disease is a disruption in blood fat levels. Muchtadi (2007) suggested that high levels of triglycerides and cholesterol (especially cholesterol-LDL) in the blood would form plaque and cause atherosclerosis. Atherosclerosis is triggered due to high levels of cholesterol in the blood (hypercholesterolemia) which is one of the factors causing coronary heart disease (Anies, 2015)

Modern pharmacological treatment and medical therapy are generally used to reduce cholesterol levels. However, long-term use would cause side effects. Adib (2009) suggested the use of cholesterol-lowering drugs might give side effects such as liver damage, gastroenteritis, irritation and inflammation of the stomach, and kidney damage if used for a long period. The use of traditional medicines such as herbs or herbal medicines is considered safer than the use of modern medicine. Javed et al. (2009) stated the use of plants as medicine against various diseases has increased, considering synthetic medicines have many side effects.

There were more than 2000 types of medicinal plants that could be used to treat heart diseases such as ischemic heart disease and hypercholesterolemia (Mahmood et al., 2010). Saraswat et al. (2010) noted several plants such as garlic (Allium sativum), ginger (Zingiber officinale), lemon (Citrus limon), and apple vinegar (Malus domestica) have effects in the treatment of heart disease. Garlic, ginger, and lemon have been consumed as a mixture of traditional drinks and are believed to provide health effects and reduce cholesterol. Javed, et al. (2014) showed that mixed herbs (garlic, ginger, apple vinegar, lemon, and honey) were effective in treating hyperlipidemia in male white rats. 
Mixed herbal drink with the composition of garlic, ginger, apple vinegar, lemon, and honey has been widely used by people as an alternative treatment for heart disease and cholesterol. Mixed herbal beverage products can be well received by the public even though many similar products are circulating in the market. However, scientific research on the properties and benefits of mixed herbal drinks has not been done much. Research related to mixed herbal drinks that have been widely circulated only includes pre-clinical trials using experimental animals so there is no further research that is directly related to humans.

The purpose of this study was to test consumer perceptions of mixed herbal drinks and the effect of mixed herbal drinks on the lipid profile of consumers with hypercholesterolemia.

\section{METHODS}

This research was an observational study using cross sectional study design. The study was conducted in urban Jabodetabek areas such as Cilandak, Dramaga, Cimanggis, Ciputat, and Jatiasih from December 2018 to March 2019. The first step in this research was conducting a survey and giving initial questionnaires that had been adapted from Hendarini (2011) and Rukmana (2016) to see the compliance characteristics of the subjects in consuming mixed herbal drinks. The second step was giving questionnaires and testing the subject's perception of perceived health benefits. The third stage was collecting medical record data that includes blood lipid profiles before and after and analysis was done using a paired sample T-test to capture changes before and after herbal drink consumption. This study has been approved by the Ethics Committee of the Human Research Ethics Committee of the Research and Community Service Institute Bogor Agricultural University No.165 / IT3.KEPMSM-IPB / SK / 2018.

The research subjects were selected by stratified random sampling, where subjects were consumers of mixed herbal drinks both men and women. Research subjects were willing to follow each stage of the study to completion by signing an informed consent, and meeting the inclusion and exclusion criteria. Inclusion criteria included consumers who use mixed herbal drinks for a minimum of 3 months, consumed mixed herbal drinks daily, aged adults ( 26 years) to seniors $(>65$ years), healthy, did not drink alcohol, supplements or other herbal product, and did not consume drugs cholesterol-related routinely while consuming mixed herbal drinks, and not being pregnant or breastfeeding. While exclusion criteria included having a history of diseases such as liver, kidney, cancer, or stroke, and participating in other studies. Calculation of the minimum number of subjects using the formula Lemeshow, et al. (1997) so as to get as many as 55 subjects.

Data was collected through interviews include subject characteristics, subject perceptions regarding mixed herbal drinks, and medical record data of subjects before and after consumption of mixed herbal drinks. Subject perceptions regarding mixed herbal drinks include health perceptions and emotional perceptions. Data collection of medical records of subjects was done 6 months before and after consumption of mixed herbal drinks.

Mixed herbal drinks had the composition of garlic, ginger, lemon, apple vinegar, and honey, which had prepared by the researchers and had been consumed by several communities as an alternative drink for treatment. Liquid mixed herbal drinks and packaged in 375 gram bottles.

The initial phase of the study was a survey of consumers of mixed herbal drinks. Consumers of mixed herbal drinks were those who purchase mixed herbal drinks with a range of adults (26 years) to seniors ( $>65$ years) of 250 men and women. Subjects were chosen based on consumers who consistently consumed mixed herbal drinks with the use of at least one spoonful a day. So that a total of 55 subjects were participated in this study.

The second step was intended to assess consumer perception toward the perceived health benefits. The perception test questionnaire was adapted using Nurbaiti (2008), Hendarini (2011) and Rukmana (2016) study. Subjects were asked to give a response whether very agree (SS), agree (S), neutral $(\mathrm{N})$, disagree (TS), or strongly disagree (STS) to the 10 statements related to the consumption of mixed herbal drinks. The last step in the study was the collection of medical record 
of blood lipid profile before and after consumption of mixed herbal drinks.

Data processing was performed using Microsoft Excel 2016 and SPSS version 16.0. Descriptive analysis was used to describe data on the subject's characteristics, nutritional status (BMI), and subjects' perceptions regarding mixed herbal drinks. Inferential statistical analysis was carried out to analyze the lipid profile level of subjects before and after consumption of mixed herbal drinks based on medical records. Paired T-test was used to see differences in the subject's lipid profile before and after consumption of mixed herbal drinks.

\section{RESULT AND DISCUSSION}

\section{Nutritional Status}

The result of this study showed that the majority of subjects $(36.36 \%)$ were in the overweight category. The cause of overweight and obesity among subjects might be due to low physical activity, consequently the greater the excess energy storage. The distribution of subjects based on nutritional status is presented in Table 1

The Ministry of Health (2018) reported that overweight and obesity were more common in women, respectively $15.1 \%$ and $29.3 \%$; whereas in men overweight is $12.1 \%$ and obesity is $14.5 \%$. Women are said to have more fat tissue than men so they are more prone to experiencing more weight and obesity. Majority of respondents

Table 1. Distribution of subjects based on nutritional status

\begin{tabular}{|c|c|c|c|c|c|c|c|c|}
\hline \multirow{3}{*}{$\begin{array}{l}\text { Nutritional } \\
\text { status }\end{array}$} & \multicolumn{6}{|c|}{ Gender } & \multirow{2}{*}{\multicolumn{2}{|c|}{ Total }} \\
\hline & \multicolumn{3}{|c|}{ Male } & \multicolumn{3}{|c|}{ Female } & & \\
\hline & n & & $\%$ & $\mathbf{n}$ & & $\%$ & $\mathbf{n}$ & $\%$ \\
\hline Normal & 1 & & 18.2 & 8 & & 14.5 & 18 & 32.7 \\
\hline Overweight & 1 & & 27.3 & 5 & & 9.1 & 20 & 36.4 \\
\hline Obese & 1 & & 25.5 & 3 & & 5.4 & 17 & 30.9 \\
\hline $\mathrm{p}$ & \multicolumn{6}{|c|}{0.192} & & \\
\hline \multirow{3}{*}{$\begin{array}{l}\text { Nutritional } \\
\text { status }\end{array}$} & \multicolumn{6}{|c|}{ Age (years old) } & \multirow{2}{*}{\multicolumn{2}{|c|}{ Total }} \\
\hline & \multicolumn{2}{|c|}{$26-45$} & \multicolumn{2}{|c|}{$46-65$} & \multicolumn{2}{|c|}{$>65$} & & \\
\hline & $\mathbf{n}$ & $\%$ & $n$ & $\%$ & $\mathbf{n}$ & $\%$ & $\mathbf{n}$ & $\%$ \\
\hline Normal & 1 & 1.8 & 17 & 30.9 & - & & 18 & 32.7 \\
\hline Overweight & 3 & 5.5 & 16 & 29.1 & 1 & 1.8 & 20 & 36.4 \\
\hline Obese & 3 & 5.4 & 14 & 25.5 & - & & 17 & 30.9 \\
\hline $\mathrm{p}$ & \multicolumn{8}{|c|}{0.535} \\
\hline
\end{tabular}

(85.5\%) were aged between 46-65 years old. There were in total 20 subjects $(36.4 \%)$ suffered overweight and 17 subjects (30.9\%) were obese. Sudikno et al. (2015) stated that factors related to overweight and obesity were age, sex, region, marital status, occupation, economic status and smoking habits. Odgen et al. (2015) showed that the adult obesity among American were more frequent in middle age (40-59 years).

\section{Health Perception}

The most common problems faced by the subjects based on the initial interview and observation of immediate condition were high cholesterol, frequent heart pain, chest tightness, abnormal palpitations, high blood pressure, easy pain, irregular bowel movements, gout, high blood sugar levels, and often dizzy. Before consuming mixed herbal drinks, $90.9 \%$ of the subjects felt an increase in cholesterol levels, $63.7 \%$ of the subjects felt the heart always aches, $69.1 \%$ of the subjects felt tightness and pain in the chest, $63.6 \%$ of the subjects felt the heart often beat irregularly, $58.1 \%$ of the subjects felt high blood pressure , $41.8 \%$ of subjects felt easy pain, $29.1 \%$ of subjects felt irregular bowel movements, $32.8 \%$ of subjects felt gout often recurred, $23.6 \%$ of subjects felt blood sugar levels increased, and $30.9 \%$ of subjects felt often experiencing dizziness.

Based on Table 2, statements one through five showed that more than $50 \%$ of subjects agree with the statement given, while in statements of six to ten more than $50 \%$ of subjects choose neutral and

Table 2. Health perception before consuming mixed herbal drinks

\begin{tabular}{lccc}
\hline \multicolumn{1}{c}{ Health perception } & $\begin{array}{c}\text { Agree } \\
(\%)\end{array}$ & $\begin{array}{c}\text { Neutral } \\
(\%)\end{array}$ & $\begin{array}{c}\text { Disagree } \\
(\%)\end{array}$ \\
\hline High cholesterol & 90.9 & 7.3 & 1.8 \\
Heart ache & 63.7 & 21.8 & 14.5 \\
The chest feels tight and & 69.1 & 12.7 & 18.1 \\
painful & 63.6 & 18.2 & 18.2 \\
Arrhytmia & 58.1 & 21.8 & 16 \\
High blood pressure & 41.8 & 38.2 & 20 \\
Easy to fall ill & 29.1 & 38.2 & 32.7 \\
Irregular defecation & 32.8 & 40 & 27.2 \\
Pain relatd to gout & 23.6 & 34.5 & 41.8 \\
Hyperglicemia & 30.9 & 41.8 & 27.3 \\
Dizziness/migrain & & & \\
\hline
\end{tabular}


do not agree with the statement given. This shows that the faced condition was more related to heart and blood vessel problems.

Table 3 confirmed that subjects who agreed with the statement from the questionnaire that was, $1.8 \%$ of subjects still felt an increase in cholesterol levels, $1.8 \%$ of subjects felt the heart was always sick, $3.6 \%$ of subjects felt tightness and pain in the chest, $3.6 \%$ of subjects felt the heart often beat irregularly , 7.3\% subjects felt high blood pressure, $1.8 \%$ subjects felt easy to fall ill, $5.5 \%$ subjects felt irregular bowel movements, $5.4 \%$ subjects felt gout often recurred, 7.3\% subjects felt blood sugar levels increased, and $10.9 \%$ subjects felt often experience dizziness. Table 4 showed the differences in health perception before and after consuming mixed herbal drinks.

The subjects relatively experienced positive perception based on Table 4. After consuming mixed herbal drinks, only $1.8 \%$ of subjects still felt an increase in cholesterol levels. Thus the subject feels decreased cholesterol levels after consuming mixed herbal drinks. This was in accordance with the research of Ifora, et al. (2016) which concluded that the provision of red ginger, garlic, honey, lemon, and apple preparations with certain doses could significantly reduce cholesterol levels. Health perception at point one to five shows positive results, where more than $50 \%$ of subjects feel the benefits of mixed herbal drinks.

\section{Emotional Perception}

Respondents' impression during the consumption of mixed herbal drink was obtained

Tabel 4. Difference in health perception before and after consuming mixed herbal drinks

\begin{tabular}{lcc}
\hline \multicolumn{1}{c}{ Health Perception } & Before (\%) & After (\%) \\
\hline High cholesterol & 90.9 & 1.8 \\
Heart ache & 63.7 & 1.8 \\
The chest feels tight and painful & 69.1 & 3.6 \\
Arrhytmia & 63.6 & 3.6 \\
High blood pressure & 58.1 & 7.3 \\
Easy to fall ill & 41.8 & 1.8 \\
Irregular defecation & 29.1 & 5.5 \\
Pain relatd to gout & 32.8 & 5.4 \\
Hyperglicemia & 23.6 & 7.3 \\
Dizziness/migrain & 30.9 & 10.9 \\
\hline
\end{tabular}

Table 5. Differences in emotional perception before and after consuming mixed herbal drinks

\begin{tabular}{lcc}
\hline \multicolumn{1}{c}{ Emotional Perception } & $\begin{array}{c}\text { Before } \\
\text { (\%) }\end{array}$ & $\begin{array}{c}\text { After } \\
\text { (\%) }\end{array}$ \\
\hline Fit body & 18.2 & 90.9 \\
Health awaken & 21.8 & 90.9 \\
Good appetite & 43.7 & 60 \\
Satisfied with the product & 16.4 & 94.6 \\
Good mood & 38.2 & 65.4 \\
Trust product's benefit & 7.3 & 96.4 \\
Feeling safe to consume the product & 90.8 & 83.7 \\
Believe that product used natural & 86.7 & 95.4 \\
ingredients & 76.1 & 87.3 \\
Like the product taste & 74.6 & 89 \\
Will recommend the product to & & \\
others & & \\
\hline
\end{tabular}

by interview and direct observation. Ten indicators were chosen to describe emotional experience of the subjects, including body fitness, health awake, good appetite, feeling satisfied with mixed herbal products, better moods, beneficial to the body, feeling safe consumption of mixed herbal drinks, originating from natural ingredients, like the taste of ingredients mixed herbal drinks; and will invite others to consume mixed herbal drinks. Table 5 shows the differences in emotional perception before and after consuming mixed herbal drinks.

Most of the subjects experienced positive emotional perception after consuming the product. Positive perceptions indicate that mixed herbal product gave positive influence, thus could soar psychological aspect of its consumer.

\section{Lipid Profie Before and After Consumption of Mixed Herbal Drink}

The results of this study showed a decrease in total cholesterol, LDL, and triglycerides before and after consuming mixed herbal drinks for 6 months. Paired T-test analysis found that there were significant differences before and after consuming mixed herbal drinks for 6 months on total cholesterol $(p=0.00)$, LDL $(p=0.00)$, and triglycerides $(p=0.00)$ presented in Table 6 . While for HDL values there was no significant difference $(\mathrm{p}=0.105)$.

The decrease in total cholesterol, LDL, and triglycerides was suspected to be due to the influence of ingredients used in mixed herbal 
Table 6. Lipid profile before and after consumption of mixed herbal drink

\begin{tabular}{lcc}
\hline \multicolumn{1}{c}{ Lipid profile } & $\begin{array}{c}\text { Before } \\
\mathbf{( m g / d L )}\end{array}$ & $\begin{array}{c}\text { After } \\
\mathbf{( m g / d L )}\end{array}$ \\
\hline Total cholesterol* & $210.56 \pm 24.25$ & $191.38 \pm 28.48$ \\
HDL & $40.44 \pm 4.27$ & $41.87 \pm 6.14$ \\
LDL* & $130.65 \pm 21.38$ & $115.6 \pm 26.21$ \\
Triglycerides* & $197.13 \pm 58.52$ & $169.31 \pm 43.51$ \\
\hline
\end{tabular}

*significantly different $(\mathrm{p}<0.05)$

drinks. Research of Handayani (2006) proven that the administration of garlic extract in ethyl acetate dissolved in soybean oil for 6 weeks decreased cholesterol and triglycerides. Hapsari (2014) showed a significant decrease of LDL among dislipidemia patient after ginger consumption. Research by Adel and Prakash (2010) showed that lemon has antioxidant activity and had an effect on lipid reduction due to the content of polyphenols, vitamin $\mathrm{C}, \beta$ carotene, flavonoids (flavonol glycosides), and tannins. Meanwhile, the research of Yohana \& Yovita (2012) suggested that the content of tannins, flavonoids, D-glucaric acid in apples suppressed LDL cholesterol level which can clog blood vessels.

Unlike the other three profiles, HDLcholesterol showed no significant difference after consumption of mixed herbal drink ( $p>0.05$ ). This could be happened because HDL levels in the blood are more influenced by physical activity. Rahmawati (2009) suggested that physical activity could increase HDL levels in the blood so that risk factors for coronary heart disease might be reduced. Mamat and Sudikno (2010) showed that respondents with less physical activity had an odd ratio to experience abnormal HDL cholesterol levels of 1.64 times $(95 \% \mathrm{CI}=1.535-1.753)$ compared to respondents with sufficient physical activity.

\section{CONCLUSION}

There were a positive changes in both health and emotional perception of the subjects after consuming mixed herbal drink. Furthermore, the results of medical records on lipid profiles showed that there was a decrease in total cholesterol, LDL cholesterol, and triglycerides before and after consuming mixed herbal drinks for 6 months ( $\mathrm{P}$ $<0.05)$.
Further research needs to be done to find out the ingredients that became the main factors to reduce cholesterol levels in the blood. It is necessary to conduct intervention research to clinically test herbal mixed beverage products.

\section{REFERENCES}

Adel, P. R., \& Prakash, J. (2010). Chemical composition and antioxidant properties of ginger root (Zingiber officinale). Journal of Medicinal Plants Research, 4(24), 2674-2679. Retrieved from https://www. researchgate.net/ publication/228476601

Adib, M. (2009). Cara mudah memahami dan menghindari hipertensi, jantung dan stroke. Jakarta: EGC.

Handayani, L. (2006). Potensi bawang putih sebagai obat tradisional/herbal dalam pelayanan kesehatan. Majalah Kedokteran Indonesia, 56(2), 64-70.

Hapsari, H. P. \& Rahayuningsih, H. M. (2014). Pengaruh pemberian jahe merah (Zingiber officinale var rubrum) terhadap kadar kolesterol LDL wanita dislipidemia. Journal of Nutrition College, 3(4), 871- 879. doi: 10.14710/jnc. v3i4.6893

Hendarini, A.T. (2011). Persepsi masyarakat terhadap manfaat kesehatan dan pengembangan produk minuman fungsional dari ekstrak daun hantap (Steculia oblongata r.brown) [disertasi yang tidak dipublikasikan]. Institut Pertanian Bogor.

Ifora, I., Dharma, S., \& Darma, D. M. (2016). Pengaruh pemberian kombinasi jahe merah, bawang putih, apel, lemon dan madu terhadap kadar kolesterol total dan histopatologis pembuluh darah aorta jantung tikus putih jantan. Jurnal Farmasi Higea, 8(2), 163-174.

Javed, I., Rahman, Z. U., Khan, M. Z., Muhammad, F., Aslam, B., \& Iqbal, Z. (2009). Antihyperlipidaemic efficacy of trachyspermum ammi in albino rabbits. Acta Vet Brno, 78(2), 229-236. doi: 10.2754/avb200978020229

Javed, I., Sarfraz, M., Muhammad, F., Aslam, B., Rahman, ZU., Khan, MZ., ... Ahmad, M. (2014). Lipid lowering effect of a herbal mixture in hyperlipidaemic adult male albino mice. Pakistan Veterinary Journal, 34(4), 480-493.

[Kemenkes] Kementerian Kesehatan RI. (2013). Laporan Nasional Riset Kesehatan Dasar (RISKESDAS) 2013. Jakarta: Badan Penelitian dan Pengembangan Kesehatan. 